\title{
Study of Stainless Steel as a Substitute for Structural Steel Reinforcement
}

\author{
R S Pawar', P R Mehetre ${ }^{2}$ \\ Research Scholar, Civil Engg Department, S.N.D. College of Engg and Research Center, Yeola, Nashik, India ${ }^{1}$ \\ Prof, Civil Engg Department, S.N.D. College of Engg and Research Center, Yeola, Nashik, India ${ }^{2}$
}

\begin{abstract}
Premature deterioration of concrete buildings and infrastructure due to corrosion of reinforcement is a severe challenge, both technically and economically. Repair-work on the public transportation infrastructure are causing significant inconveniences and delays for both the industry and the general public, and are now recognized as a substantial cost for the society. The scope of this project is to increase the durability and service life of concrete structures exposed to corrosive environments by focusing on two issues: Eliminating reinforcement by examining the core of the problem, i.e. the reinforcement itself, Overcoming the technical knowledge gap for application of stainless steel reinforcement in concrete structures.
\end{abstract}

Keywords: Corrosion Resistance, Life Cycle Cost, Stainless Steel, Reinforcing Bar.

\section{INTRODUCTION}

Premature deterioration of concrete buildings and infrastructure due to corrosion of reinforcement is a severe challenge, both technically and economically. It has been estimated that western europe spends 5 billion euros yearly for repair of corroding concrete infrastructures. Repair-work on the public transportation infrastructure are causing significant inconveniences and delays for both the industry and the general public, and are now recognized as a substantial cost for the society. The main sources of chloride ingress stems from seawater splash (on marine based structures) as well as from de-icing salts (on roads, bridges, parking decks and on external staircases and access balconies in large condominiums). Carbon steel reinforcement embedded in concrete will not normally corrode due to the formation of a protective ion-oxide film, which passivates the steel in the strong alkaline conditions of the concrete pore water. However, this passivity may be destroyed by chlorides penetrating through the concrete, or due to carbonation, reaching the surface of the reinforcement. Corrosion, which is an electrochemical process involving establishment of corroding and passive sites on the steel surface, may then be initiated.

As a result of corrosion reaction, rust forms and occupies a volume of up to 6-7 times that of the original metal, hence generating bursting forces. These forces might exceed the tensile strength of concrete, causing cracking and spalling of the concrete leading to further corrosion and loss of bond between the concrete and the steel. Hazardous situations might occur when pieces of spalled concrete fall and threaten the user or passer-by, or when the structural member looses cross-sectional area and thereby experiences increased stress on the remaining section, which potentially could lead to structural failure.

\section{Necessity}

Stainless steels have not traditionally been widely used as structural materials in building and civil engineering. Where the steels have been used for this purpose there has been some other imperative driving the design, usually corrosion resistance or architectural requirements rather than the inherent structural properties of the steel. The primary reason for this low use in structural applications is usually the perceived and actual cost of stainless steel as a material. Developments over the last 10 years, both in available materials and attitudes to durability, are now offering a new opportunity for stainless steels to be considered as primary structural materials.

\section{Objective of study}

Replacing conventional carbon steel reinforcement with corrosion resistant steel reinforcement or with non-metallic reinforcement has only received limited attention in the Nordic countries. While non-metallic reinforcement (carbon-, aramid- or glass fibre) still is in a $R \& D$ phase, corrosion resistant steel reinforcement in the form of stainless steel reinforcement (SSR) has been readily available commercially for the last say 10 years. The use of SSR has so far been limited mainly due to high costs and lack of design guides and standards.

\section{Chemical Composition}

In order to compare stainless steel grades with different alloying, correlation of the influence of the different elements has been made resulting in the expression of pitting resistance equivalent number (PREN). This expression can be 
UGC Approved Journal

IARJSET

Vol. 4, Issue 6, June 2017

considered as a relative measure of the total resistance resources for the steel grade and thus as a comparable value for ranking the corrosion resistance against chloride pitting corrosion. The expression is calculated from the content of the alloying elements in the steel grade. For austenitic steels the expression is:

$$
\text { PREN }=\% \text { Chromium }+3,3 * \% \text { Molybdenum }+16 * \% \text { Nitrogen }
$$

For duplex steels the effect of nitrogen is considered higher resulting in the expression

PREN $=\%$ Chromium $+3,3 * \%$ Molybdenum $+30 * \%$ Nitrogen

The susceptibility to pitting corrosion increases with the decrease in PREN value. Examples of commercially available standard grades, which can be used in concrete, and their pitting resistance equivalent number, are shown in Table 3-1. The PREN values have been developed to represent the level of corrosion resistance of different grades of stainless steel to be used directly exposed to a corrosive environment. Therefore the values cannot be directly transferred to represent the absolute pitting corrosion resistance of SSR cast into alkaline concrete. But the values represent the best available relative measure of the pitting corrosion resistance of the SSR exposed to chlorides in concrete.

TABLE I CLASSIFICATION OF STAINLESS STEEL ACCORDING TO INTERNATIONAL STANDARDS, AND CORRESPONDING PREN VALUES

\begin{tabular}{|c|c|c|c|c|c|c|}
\hline \multirow[t]{2}{*}{ Steel Type } & \multicolumn{2}{|c|}{ Steel grade } & \multirow{2}{*}{$\begin{array}{l}\text { USA } \\
\text { AISI } \\
\end{array}$} & \multirow{2}{*}{$\begin{array}{c}\text { Great Britain } \\
\text { BS }\end{array}$} & \multirow{2}{*}{\begin{tabular}{|c|} 
Sweden \\
SS \\
\end{tabular}} & \multirow[t]{2}{*}{$\begin{array}{l}\text { PREN } \\
\text { value }\end{array}$} \\
\hline & EN 10088-1 & Designation & & & & \\
\hline Austenitic & 1.4301 & $\begin{array}{c}\mathrm{X} 5 \mathrm{CrNi} \\
18-10 \\
\end{array}$ & 304 & $314 S 11 / 314 S 15$ & 2332 & 19 \\
\hline \multirow{4}{*}{ Austenitic } & 1.4401 & $\begin{array}{c}\text { X5CrNiMo } \\
17-12-2 \\
\end{array}$ & 316 & $316 \mathrm{~S} 33$ & 2347 & 25 \\
\hline & 1.4429 & $\begin{array}{c}\mathrm{X} 2 \mathrm{CrNiMoN} \\
17-13-3 \\
\end{array}$ & 316LN & $316 S 63$ & 2375 & 26 \\
\hline & 1.4436 & $\begin{array}{c}\text { X5CrNiMo } \\
17-12-2 \\
\end{array}$ & 316 & & 2343 & 26 \\
\hline & 1.4571 & $\begin{array}{c}\text { X6CrNiMoTi } \\
17-12-2 \\
\end{array}$ & $316 \mathrm{Ti}$ & & 2350 & 25 \\
\hline \multirow{2}{*}{$\begin{array}{c}\text { Ferritic- } \\
\text { austenitic } \\
\text { (lean duplex } \\
\text { types) }\end{array}$} & $\begin{array}{c}1.41 \times x \\
\text { (LDX 2101) }\end{array}$ & $\begin{array}{c}\text { X3CrNiMo } \\
22-2-0 \\
\end{array}$ & - & - & - & 26 \\
\hline & 1.4362 & $\begin{array}{c}\text { X2CrNiMo } \\
23-4\end{array}$ & - & - & - & 24 \\
\hline $\begin{array}{l}\text { Ferritic- } \\
\text { austenitic } \\
\text { (Duplex) }\end{array}$ & 1.4462 & $\begin{array}{c}\mathrm{X} 2 \mathrm{CrNiMoN} \\
22-5-3\end{array}$ & - & 318 & 2377 & 36 \\
\hline
\end{tabular}

EN grades are given steel numbers in groups:

$1.40 x \times$ for grades with $<2,5 \% \mathrm{Ni}$, without $\mathrm{Mo}$, without special additions;

$1.41 x x$ for grades with $<2,5 \% \mathrm{Ni}$, with $\mathrm{Mo}$, without special additions,

$1.43 x \times$ for grades with $\geq 2,5 \% \mathrm{Ni}$, without $\mathrm{Mo}$, without special additions;

$1.44 x \times$ for grades with $\geq 2,5 \% \mathrm{Ni}$, with $\mathrm{Mo}$, without special additions;

$1.45 x x$ and $1.46 x x$ for grades with special additions, such as $\mathrm{Ti}, \mathrm{Nb}$ or $\mathrm{Cu}$

Corrosion Properties of Stainless Steel Reinforcement

The types of corrosion, which in general can occur on stainless steels, are the following:

- Uniform Corrosion

- Galvanic Corrosion

- Pitting Corrosion

- Stress Corrosion Cracking

- Crevice Corrosion

- Atmospheric Corrosion

- Intergranular Corrosion

- Corrosion Fatigue. 
UGC Approved Journal

IARJSET

Selective Application of Stainless Steel Reinforcement

Stainless steel reinforcement has been used in a wide range of applications, such as bridges, tunnels and underpasses, retaining walls, foundations, marine structures, historic buildings and other structures with special long service lives in the last 30 years.
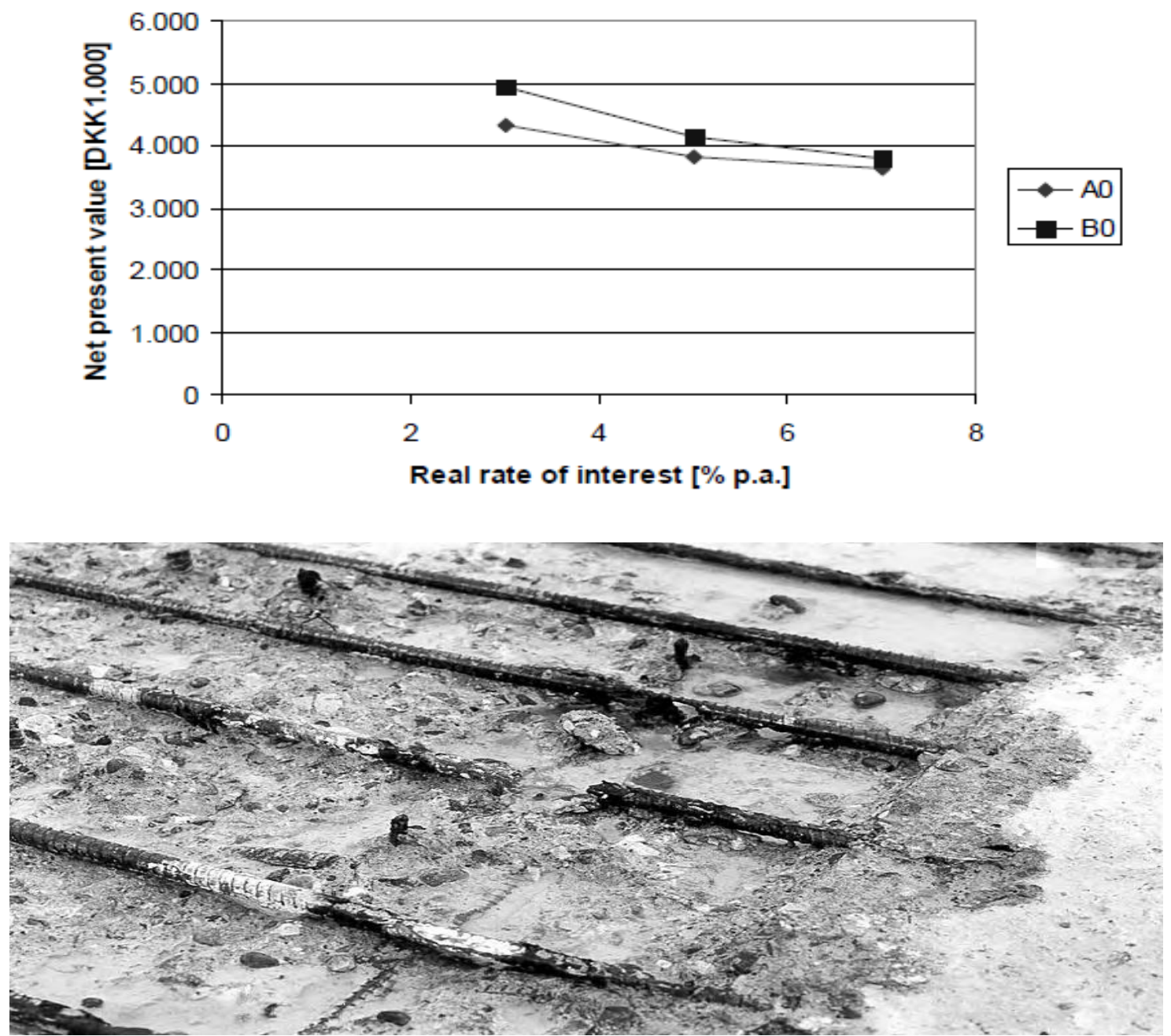

Fig No 1.Corroded Carbon Steel Reinforcing Bar In elevated roadway of Gardner Expressway, Toronto, Canada.

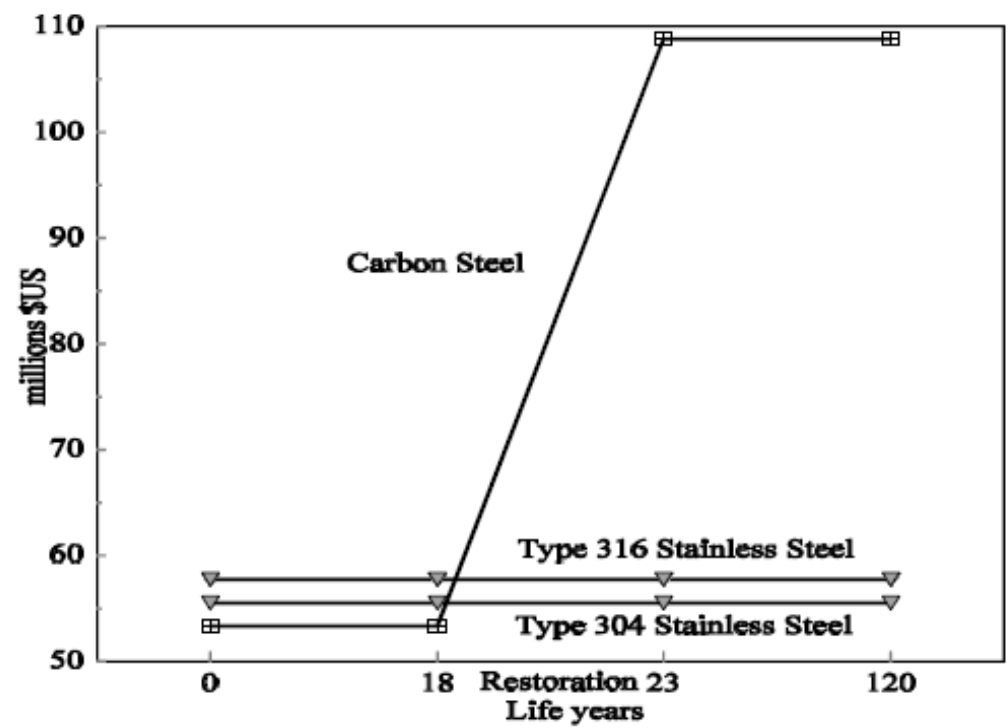

Fig.no 2. Life Cycle Cost For The Öland Bridge, Sweden. 
The most cost optimal solution is to use SSR in the most exposed ones/parts of the structure. For bridges it could be in edge beams, expansion joint sections, piers and piers tops and bridge deck soffits. Typical potential application of SSR in marine and offshore structures includes piers and soffits of jetties, part of oil rigs in the tidal or splash zones, exposed face of building close to the shoreline, seawalls etc.

The selective use approach is illustrated in Figure 8-1 and Figure 8-2, showing a large building complex in the Gulf region. SSR (1.4462) was here introduced from somewhat below groundwater level to level $+5 \mathrm{~m}$ in the outermost structures directly exposed to the salty ground water and seawater spray of the Gulf. All remaining parts are reinforced with normal carbon steel. At the same time the reinforced concrete seawall protecting the new building complex is being replaced using SSR (1.4462) throughout.

\section{CONCLUSION}

- In recent years there has been an increasing interest in applying stainless steel reinforcement (SSR) in concrete structures to combat the durability problems associated with chloride ingress.

- A convincing documentation of the performance of stainless steel reinforcement in highly chloride contaminated concrete is presented by the 70 year old concrete pier at Progresso in Mexico. This pier was reinforced with stainless steel reinforcing bars (quality 1.4301) and no corrosion has taken place within the structure yet despite the harsh environment. The chloride levels, at the surface of the reinforcement are more than 20 times the traditionally assumed corrosion threshold level for carbon steel.

- It may be concluded that designing structures with SSR may in principle be performed by a simple replacement of ordinary carbon steel reinforcement with SSR in the ratio 1:1 as the structural properties are the same regarding strength and ductility (or better for several of the available types of SSR). Further, using SSR in design other advantages should also be utilized, such as: relaxation of concrete cover requirements, crack width requirement, and maybe concrete quality (permeability) requirements.

- An important fact is that stainless steel reinforcement can be combined with black steel cast into concrete without risks of galvanic corrosion due to bi-metal - or galvanic - action. In fact, this is the precondition for general economical application of stainless steel reinforcement used only in the parts of the structure where this protection is needed, - so-called selective use.

- Ribbed stainless steel reinforcement is available in a number of different material grades. Choice of material grade should depend on the design service life and the environmental aggressivity.

\section{REFERENCES}

1) Tuutti, K., "Corrosion of steel in concrete", CBI research, vol. 4, Cement- ochbetong institute, 1982 "Model code for service life design", fib, Bulletin No. 34, February 2006.

2) Rostam, S., "Philosophy of Assessment and Repair of Concrete Structures, and the Feedback into New Designs", Regional Conference on Damage Assessment, Repair Techniques and Strategies for Reinforced Concrete, Bahrain, December, 1991.

3) Kilworth, S. R., Fallon, J., "Stainless Steels for Reinforcement", development of the paper"Fusion Bonded Epoxy Coated Reinforcement in the Gulf", presented at the Corrosion and Protection of Reinforced Concrete Conference, Dubai, 1994.

4) Jennifer L. Kepler Evaluation of Corrosion Protection Methods For Reinforced Concrete Highway Structures University Of Kansas Center for Research, Inc. Lawrence, Kansas May 2000.

5) Shiokawa Takashi Applications Of JFE443CT Steel Developed As A Substitute For SUS304 JFE Technical Report No. 12 (Oct. 2008) 